the three elements only to which Mr. Amery referred, the ninety million Moslems, the scheduled castes who stand outside the main Hindu community represented by Congress, and thirdly, the Indian princes whose territory covers a third of all India. These differences are based upon a long and powerful tradition rooted in religious belief and social regulation. They are, Mr. Amery said in speaking more particularly of the Muhammadans, "as deep as, if not deeper, than any similar differences in Europe". Because they impinge upon what is most vital in the life of the people, namely, their religious beliefs and cultural beliefs, and because they are faced with the familiar urge of Hinduism to absorb and assimilate, they emerge in the form of a profound mistrust of majority rule.

Mr. Amery himself does not despair of the situation. As he told the House, he does not regard the differences between these conflicting elements in India, which have been the subject of negotiation since October last, as unbridgable. That in actual practice they may be bridged is shown by the cooperation of individual members of the Moslem community, who have taken an active part in the work of the Congress party. In the main, however, he relied upon two factors. In the first place, whatever may be the barriers between the component elements, India is a distinct cultural unity, a selfcontained and distinctive region of the world, boasting an ancient civilization and a long history common to all her peoples, of which all Indians were equally proud; and secondly, all parties are at one in their detestation of Nazi aggression and their endorsement of our common cause. Common effort in the present emergency and the opportunity for discussion and the promotion of understanding pending post-War deliberations cannot but strengthen these two forces making for unity, and help to bring about that readiness to accept agreement based upon compromise of rule by consent which is "the foundation of all free government and of all true democracy". By India's aptitude in displaying these qualities in the immediate future will her full and free acceptance of the democratic ideal be judged.

\section{Causes of Accidents in Factories}

Evidence submitted by the National Federation of Professional Workers before the Royal Commission on Workmen's Compensation on May 16 calls for a revision of the maximum benefits payable and attaches great importance to replacing the flat rate maximum by payments proportionately related to earnings already recognized in the payments for partial incapacity. It was also urged that there is no justification for such a salary limit as exists at present. The Federation expressed the opinion that extension of the salary limit or its entire elimination would not upset the structure or balance of the Act. It was further urged that compulsory insurance should be extended to all classes of employment and the doctrine of common employment abolished as a defence against claims under the common law.

In a memorandum of evidence submitted it was stated that the majority of accidents in factories occur owing to the negligence of employees, and in an examination on this memorandum the representatives of the National Federation of Professional Workers stated that in many engineering concerns most of the accidents are due to negligence or, what was worse than negligence in a sense, some breach of statutory regulations or statutory duties. The failure of the material is often a matter of negligence at some more remote period and the Federation's conception of negligence was that it began in the Board Room. Breakdown of material, for example, could generally be attributed to failure to inspect sufficiently frequently, and in very busy works a good deal was taken for granted without inspection. It is considered that many safeguards could be arranged as an integral part in the design of the machine, and that is increasing in many makes of machinery. It was urged that much could be done in the drawing office rather than after the machine is installed to prevent accidents.

In explaining that the majority of accidents in factories occur owing to the negligence of employees, it was held that accidents are not caused by the negligence of the injured employee and this was linked up with the doctrine of common employment according to which where an injury arises owing to the negligence of a fellow employee the injured man cannot take an action. Apart from what one might call natural accidents it was safe to say that every accident occurs through some human agency. Much negligence, it was brought out in further evidence, was not necessarily culpable but might be due to fatigue. The Federation did not agree to a distinction between accidents due to the negligence of a manager or someone in special authority under a manager and accidents due to the negligence of the ordinary fellow worker. It is considered reasonable to hold the employer responsible for damages even when the negligence was not on the part of any official but on that of a fellow worker.

\section{Blow-Guns for Clearing Away Dust in Factories}

Accidents occur every year as the result of attempts to clear away dust, etc. by hand from moving machinery or electrical apparatus. Using rags or brushes for this purpose is often very dangerous. According to Engineering of July 26, pneumatic blow-guns are proving very useful for this purpose. They weigh only half a pound and are easily handled even in very awkward positions. The blow-gun is intended for use in workshops where compressed air is available, and below the hand-grips it has a hose connexion. The body is of aluminium and the renewable nozzle is of bronze. The nozzle can have a bore of $\frac{1}{16}$ in., $\frac{1}{8}$ in. or $\frac{5}{32}$ in., as desired. If used near live electrical fittings, it is made of insulating material so that safe operation is assured if accidental contact is made. Control of the air jet is effected by a push button actuated by the forefinger of the hand holding the gun. The valve is readily renewable.

It is stated that the blow-gun has proved most useful in blowing dust from foundry moulds and is particularly effective in getting rid of the dust 
formed in machining operations in non-metallic materials, such as plastics, this dust being difficult to displace by means of brushes or rags. In woodworking machinery it is very useful in removing sawdust and shavings. To enable the gun to be readily connected to existing air supplies, the manufacturers have developed a neat pressure-reducing tube valve manufactured from bronze pressings and having a diaphragm of the oil-resisting rubber insertion type. The valve will reduce an initial pressure of $150 \mathrm{lb}$. per sq. in. to any pressure between $5 \mathrm{lb}$. and $100 \mathrm{lb}$. per sq. in., the adjustment being made by a thumb screw. The valve has a nickelplated finish and is stated to be unaffected by oil or water and does not vibrate or chatter when in use.

\section{War, Tradition and Natural Beauty}

IN a war, which in so far as the greater includes the less, is being fought by the British people in defence of an ideal of the spirit which, we maintain, has run like a thread throughout our history, it is vital that every effort should be made to keep alive, even if necessary in attenuated form, activities which make for the preservation of the national tradition as embodied in our antiquities and places of historic interest, or in those vistas of our landscape which are not only beautiful in themselves, but also express something which is essentially in harmony with characteristics of the mentality of the British peoples. The recent pronouncement of the Council for the Preservation of Rural England makes a bold bid to reconcile claims arising out of present necessities with its objective of saving rural beauties from desecration.

How difficult this may become is strikingly illustrated in the recently issued report for 1939-40 of the National Trust. Here and there in the brief notes on the properties held by the Trust a hint is given of the difficulties which are being, or have had to be, overcome by those responsible for carrying out the objects of the Trust in securing that these objects shall not be irrevocably overridden, if that is at all possible, by the requirements of military authority or the necessities of food supply. The normal expansion of the work of the Trust cannot be expected to continue unimpaired in present conditions; and indeed the annual report for the period under review chronicles a reduction in receipts, not, indeed, as great as might be anticipated, which will make the realization of even working costs a matter of some anxiety. The work of the Trust, however, is, as has been said, of vital importance in maintaining much that is of the best in the national tradition, and its claims to public support should be among the last to be overlooked. An indication of the activity of the Trust in recent years is afforded by a comparative table given in the annual report, which shows that in the period 1914-40 there has been a tenfold increase in most of the figures. The number of properties has increased from 63 to $4 \mathrm{I} 0$, the acreage from 5,814 to 58,900 ; the capital raised and expended from $£ 59,861$ to $£ 530,114$, subscriptions from $£ 559$ to $£ 6,193$, and the gross income from properties from $£ 1,461$ to $£ 27,553$.

\section{Preserves from the Garden}

"Growmore" Bulletin No. 3, of the Ministry of Agriculture and Fisheries (H.M. Stationery Office, $4 d$.), presents in a concise and practical form instruction for the housewife in the preservation of surplus fruit and vegetables for winter use. Full directions are given for the making of jams, fruit jellies, cheeses, and syrups, and the bottling and canning of fruit and vegetables. Instructive notes are provided on the peculiarities of particular fruits and their suitability for the various methods of preservation. A selection of recipes for jam and jelly made from the more important fruits is included, and in some of these the normal amount of sugar has been reduced to meet the difficulties of sugar shortage. A useful feature is a statement of the expected yield of jam from the amounts of fruit used. Various methods are given for sterilizing fruit for canning and bottling and the preservation of fruit in the form of pulp. The latter is a useful method for the storage of large quantities of apples and plums without sugar.

The preservation of vegetables is not so widely practised as that of fruit, and as pressure cookers are recommended for vegetable sterilization, this method will not be extensively used in the average household Several vegetables may, however, be preserved by pickling, which is briefly dealt with in the bulletin. Salted runner beans are invariably satisfactory, and as salt is cheap and the method simple, more use should be made of this usually prolific crop. Many fruits and vegetables can be dried for future use, a method which needs no preservative, and is adequately treated in this bulletin. The authors, Alice Crang and Margery Mason, have produced a very usable handbook, and are to be congratulated on the selection of the most useful and straightforward methods, as well as on the omission of technical details which are of little interest to the average housewife.

\section{Organized Labour in Germany}

Alrhough written rather as if to prove a point, Dr. W. A. Robson's pamphlet, "Labour under Nazi Rule" (Oxford Pamphlets on World Affairs, No. 33. Pp. 32. Oxford: Clarendon Press. 3d. net) gives a concise and lucid account of the sweeping changes made by the Nazi regime in the status and organization of labour, from the liquidation of the highly progressive German working-class movement in 1933 to the system of unmitigated industrial conscription introduced since 1938. Prior to 1933, Germany was one of the most progressive countries in the world so far as the position of organized labour was concerned. By showing the extent to which industrial servitude and regimentation have been exacted as the price of Hitler's achievement in abolishing unemployment, Dr. Robson puts that achievement in its true perspective along with the Labour Front and the 'Strength through Joy' movement. This admirably written account of the present position of organized labour in Germany and the way in which it has arisen fully substantiates Dr. Robson's central thesis that the status, freedom, power, and conditions of 